\title{
Encyklika Papieża Piusa XII z dnia 15 maja 1956 r. dotycząca kultu Najświętszego Serca Jezusowego
}

Papież Pius XII przesyła Wam, Czcigodni Bracia, pozdrowienie i błogosławieństwo apostolskie!

HAURIETIS AQUAS - „Będziecie czerpać z radością wody ze zdrojow Zbawicielowych" ${ }^{1}$ ). Prorok Izajasz takimi słowami w symbolicznych obrazach zapowiadał te przeróżne i nader obfite dary Boże, które miała przynieść epoka chrześcijańska. Przychodzą nam na myśl te słowiva, gdy wspominamy setną rocznice tej chwili, w której Poprzednik Nasz, Pius IX przyjął radośnie napływające doń z całego świata życzenia i prośby i rozszerzył uroczystość ku czci Najświętszego Serca Jezusowego na cały. świat.

Wprost nie można zliczyć tych wszystkich łask, które z kultu Najśw. Serca Jezusa spłynęły na ludzi, ile dusz oczyściły z grzechów, obdarzyły niebiańską radością, pobudziły do zdobywania wzniosłych cnót. Nawiązując do głębokich słów świętego Jakuba Apostoła: „,Wszelki dar dobry i każda wielka łaska z wysoka pochodzi, zstępuje od Ojca światłości" "), możemy śmiało twierdzić, że w tym kulcie, który coraz potężniej rozwijał się w świecie, widzimy bezcenny dar Słowa Wcielonego, Boskiego Zbawiciela. Jako jedyny Pośrednik laski i prawdy Jezus dał ten dar Kościołowi, swojej mistycznej Oblubienicy, w tych najnowszych czasach mającym do wykonania tyle wielkich prac i olbrzymich trudności do pokonania. Dzięki temu darowi o bezcennej wartości Kościól mógł czynnie okazać swoją miłość dla naszego Boskiego Założyciela i lepiej odpowiedzieć na wezwanie Jezusa podane nam przez św. Jana: „A w ostatnim wielkim dniu święta stanął Jezus i zawołał mówiąc: „Jeśli kto pragnie, niech do Mnie przyjdzie, a pije - który wierzy we Mnie, jak mówi Pismo święte, rzeki wody żywej popłyną z jego wnętrza. A to mówił o Duchu, którego otrzymać mieli wierzący wen'"3).

Dla słuchaczy Jezusa nie było trudno to powiedzenie Jego o ,wodzie żywej" z Niego wypływającej złączyć z wypowiedziami Izajasza, Ezechiela, Zachariasza o królestwie Mesjańskim i ze wspomnieniem skały, z której za dotknięciem laski Mojżesza wypłynęly obfite strumienie $\operatorname{wody}^{4}$ ).

Miłość Boża wywodzi się z Ducha świętego, który jest miłością osobową łączącą Ojca z Synem w łonie Najświętszej Trójcy. Słusznie Apostoł Narodów, zgodnie ze słowami Jezusa, przypisuje wylanie miłości

1) Is. 12,3 .

2) Jac. 1, 17.

3) Jo. $7,37-39$.

4) Cfr. Is. 12,3 ; Ez. 47, 1-12; Zach. 13, 1; Ex. 17, 1-7; Num. 20, 7-13;

1 Cor. 10,4 ; Apoc. $7,17,22,1$. 
na dusze wiernych temuż Duchowi Miłości: „Miłość Boża rozlana jest w sercach naszych przez Ducha świętego, który nam jest dany" ${ }^{5}$ ).

Najściślejszy ten węzeł, który według Pisma świętego ma zapalić miłość Bożą w sercach ludzkich i połączyć je z Duchem świętym, który sam przez się jest Miłością, dowodzi wymownie, jaka jest najgłębsza istota kultu Najśw. Serca Jezusa. Gdy rozważamy, jaka jest właściwa cecha tego kultu, co jest jego naturą, widzimy w tym kulcie najwznioślejszy akt religii, który wymaga pełnego i bezwzględnego poświęcenia się miłości Boskiego Zbawiciela, miłości, której Serce zranione jest żywym znakiem i symbolem. Rzeczywiście i to w głębszym jeszcze znaczeniu, kult ten tym się znakomicie wyróżnia, że miłością odpowiadamy na miłość Zbawiciela. To przecież tylko siła miłości to sprawia, że dusze ludzkie oddają się całkowicie i doskonale pod panowanie Boga a uczucia ludzkie tak łączą się z wolą Bożą, że stają się czymś jednym: „Kto łączy się z Panem, jest z Nim jednym duchem"6).

\section{Podstawa kultu N S J w St. Zakanie}

\section{a) wyjaśnić nieporozumienia wśród katolików}

Chociaż Kościół zawsze bardzo wysoko cenił i ceni kult Najśw. Serca Jezusa i usilnie stara się rozwijać ten kult wśród narodów chrze-ścijańskich i wszelkimi sposobami bronić przeciw napaściom n a turalizmu i sentymentalizmu, to ubolewać trzeba nad tym, że i w dawnych czasach i w obecnych kult tak znakomity nie wszędzie był należycie oceniony przez niektórych chrześcijan, czasem nawet przez takich, którzy uważają siebie za katolików dążących do świętości.

„Gdyby znał dar Boży!“7). Wraz z tym słowem, Czcigodni Bracia, kierujemy do was Nasze ojcowskie wezwanie, jako przez zrządzenie Boże powołani na stróża i rozdawcę skarbu wiary i pobożności danego przez Zbawiciela Kościołowi. Chociaż kult NSJ triumfuje mimo błędów i obojętności wielu ludzi i przenika Ciało mistyczne Zbawiciela, niektórzy nasi synowie żywią jeszcze wobec tego kultu pewne uprze-dzenia, myślą, że w naszych czasach mniej się przydaje, a może nawet jest szkodliwy dla potrzeb duchowych Kościoła i ludzkości.

Nie brak takich, którzy istotę i naturę tego kultu lączą z pewnymi praktykami, które Kościół wprawdzie zatwierdza, ale nie nakazuje i uważają ten kult jako coś dodatkowægo, zbędnego, co każdy może dowolnie praktykować lub opuszczać, wedle swego uznania. Inni uważają ten kult za zbyt uciążliwy i bez żadnego lub niklcgo pożytku zła zwłaszcza dla tych, którzy walczą o królestwo Boże, siły swoje, środki i czas poświęcają na głoszenie nauki chrześcijańskiej, zwłaszcza w sprawach społecznych, rozwijają działalność religijną taką, która

\footnotetext{
5) Rom. 5, 5.

$\left.{ }^{6}\right) 1$ Cor. 6,17 .

7) Jo. 4, 10 .
} 
uważają za najpotrzebniejszą dzisiaj. Są i tacy, którzy kultowi temu nie odmawiają znaczenia i ważności jako pomocy dla odnowienia obyczajów chrześcijańskich w życiu osobistym i rodzinnym, ale widzą w nim rodzaj pobożności oparty raczej na uczuciach niż na rozumie, więcej odpowiedni dla kobiet, mniej przydatny dla ludzi wyksztalconych.

Są zwłaszcza tacy, którzy uważają że ten kult domaga się przede wszystkim pokuty, ekspiacji, innych cnót tzw. ,pasywnych“, biernych, nie dających zewnętrznych owoców i dlatego nie jest odpowiedni do rozwoju pobożności potrzebnej naszym czasom. Ich zdaniem, dzisiejsza pobożność winna zmierzać do twartej i energicznej akcji, prowadzić do triumfu wiary katolickiej, do ścisłego przestrzegania obyczajów katolickich. Te zaś obyczaje, jak wszystkim wiadomo, łatwiej ulegają zakażeniu przez zwodnicze poglądy takich, którzy zajmują postawę taką samą wobec jakiejkolwiek formy religijnej, nie uznają różnicy pomiędzy dobrym i złym, a nawet, niestety, ulegają zasadom $\mathrm{m} a-$ terializmu i laicyzmu.

\section{b) Papieże o czci dla Najśw. Serea Jezusa}

Takie opinie nie zgadzają się z tym, co glosili Nasi Poprzednicy $z$ tej stolicy prawdy, gdy wydawali publiczne dekrety i zatwierdzali kult NSJ. Któż ośmieli się mówić, że dla naszych czasów jest niepożyteczna i nieodpowiednia ta pobożność, którą Nasz Poprzednik, Leon XIII, uważał ,za najbardziej wypróbowaną formę religijności“, za skuteczne lekarstwo dla uleczenia tych chorób naszych czasów, które dzisiaj o wiele szerzej i ostrzej atakują i rujnuja pojedynczych ludzi i cale spoleczeństwa. „To jest nabożeństwo, które doradzamy wszystkim, bo wszystkim ono przyniesie pożytek'. I dodawał upomnienia, które odnoszą się także do kultu NSJ: ,Wielka jest moc zła, które od dawna czyha na nas, przeciw któremu bardzo potrzebna jest ta jedyna pomoc, jedynie tu skuteczna i zwycięska. Któż może pomóc poza Jezusem Chrystusem, Jednorodzonym Synem Bożym?!“ — „Nie ma żadnego innego imienia pod niebem, danego ludziom, w którym mielibyśmy być zbawieni!" 8). Trzeba więc udać się do tego, który jest życiem, prawdą i drogą“" ${ }^{9}$ ).

Bezpośredni nasz Poprzednik, Pius XI, uważał również kult NSJ za bardzo godny uznania i bardzo przydatny do rozwoju pobożności. Pisał w swojej encyklice: „Czyż w tej formie pobożności nie zawiera sic̨ jakby summa, cała treść naszej religii i norma doskonalszego życia? Przecież ta pobożność prowadzi najlepiej do dokładniejszego poznania Chrystusa Pana, do głębszego umiłowania Chrystusa i dosko-

$\left.{ }^{8}\right)$ Act. 4, 12.

$\left.{ }^{9}\right)$ Enc. Annum Sacrum, 25 Maii 1899; Acta Leonis vol. 19, 1900. pp. $71,77-78$. 
nalszego naśladowania!" ${ }^{10}$ ). Nam samym, nie mniej niż naszym Poprzednikom, ta prawda wydaje się całkiem widoczna i całkowicie godna potwierdzenia. Na początku Naszego Pontifikatu zaraz w Naszej pierwszej encyklice daliśmy wyraz naszej radości na widok triumfalnego wzrostu kultu NSJ wśród chrześcijan i niczliczonych zbawczych skutków tego kultu dla całego Kościoła. W ciągu długich lat Naszego Pontyfikatu jego owoce nie zmniejszyły się ani co do jakości i piękności, ani co do liczby, owszem raczej wzrastały. A byly to lata pełne nie tylko trosk i przeciwności, ale także obfite w wielkie radości.

Do rozwoju kultu przyczyniły się różne szczęśliwe inicjatywy i nowe pomysły ,bardzo odpowiednie dla naszych czasów, stowarzyszenia dla rozwoju kultury, religii i dobroczynności, ukazały się drukiem dzieła z zakresu historii, ascetyki, mistyki odnośnie kultu NSJ, wielki wpływ miały publikacje „Apostolstwa Modlitwy“, za jego to' staraniem odbywały się liczne poświęcenia rodzin, kollegiów, instytutów nawet calych narodów Najśw. Sercu Jezusa. Chętnie braliśmy udział w tych uroczystościach przez Nasze listy, przemówienia zwykle i przez radio ${ }^{12}$ ).

Gdy widzimy te nader obfite potoki wód, czyli zbawiennych łask ze Serca Odkupiciela za natchnieniem Ducha świętego odpływających do niezliczonych mas katolików, nie możemy powstrzymać się, by nie wezwać was, Czcigodni Bracia, byście wraz z Nami najwyższe złożyli dzięiki Dawcy wszelkich dóbr, Bogu, wedle słów Apostoła: „Temu, który mocen jest uczynić daleko więcej, niż o to prosimy, albo pojmujemy, według działającej w nas mocy, - Jemu niech będzie chwala w Kościele i w Chrystusie Jezusie na wszystkie czasy i na wieki wieków - Amen" ${ }^{13}$ ).

Skoro złożyliśmy należne dzięki Bogu wiecznemu, teraz pragniemy tą encykliką wezwać Was i wszystkich najdroższych synów Kościoła, byście z wielką pilnością poznali poglądy Biblii, Ojców Kościoła i teologów na fundamentalne zasady kultu NSJ. Jesteśmy najmocniej przekonani, że dopiero wtedy, przy pomocy światła prawdy objawionej przez Boga, poznacie zasadniczą, najgłębszą istotę kultu NSJ, wtedy dopiero będziecie mogli należycie ocenić niezrównaną wzniosłość i niewyczerpalne bogactwa darów niebieskich. Z pobożnego rozważania i kontemplacji dobrodziejstw tego kultu wynikną głębsze motywy do godnego uczczenia pierwszego stulecia od chwili rozszerzenia uroczystości ku czci NSJ na cały Kościół.

Chcemy chrześcijanom podać dobre materiały do rozmyślań i rozważań, by łatwiej mogli poznać istotę tego kultu i zbierać zeń więk-

\footnotetext{
p. 167

11) Cfr. Enc. Summi Pontificatus, 20 Octob., 1939; A. A. S. 31, 1939, p. 415.

12) Cfr. A. A. S. 32,1940 , p. $276 ; 35,1943$ p. $170 ; 37,1945$, pp. 263-264; 40,1945 , p. $501 ; 41,1949$, p. 331.

13) Eph. 3, 20-21.
}

${ }^{10)}$ Enc. Miserentissimus Redemptor, 8 Maii 1928, A. A. S. 20, 1928, 
sze pożytki. Zatrzymamy się w tym celu nad niektórymi kartami Starego i Nowego Zakonu, które zawierają objawienia i opisy nieskończonej miłości Boga dla rodzaju ludzkiego, miłości, której nigdy dostatecznie nie zdolamy poznać. Wspomnimy i przytoczymy także komentarze Ojców Kościoła i Doktorów, wreszcie postaramy się naświetlić tę najdoskonalszą łączność, jaka istnieje pomiędzy tą formą pobożności, którą czcimy Serce Boskiego Zbawiciela a kultem należnym miłości Zbawiciela i miłości Trójcy świętej za miłiść dla całej ludzkości. Ufamy, że gdy w świetle Pisma świętego i Tradycji poznamy podstawy i współczynniki zasadnicze tego kultu, wtedy chrzecijanie łatwiej będą czerpać ,wody ze zdrojów Zbawicielowych"14), lepiej doceniać ważność kultu NSJ i jego właściwe miejsce w liturgii Kościoła, w jego życiu wewnętrznym i zewnętrznym, w jego pracy i dziełach. Wtedy też będą mogli zbierać duchowe owoce dla odnowienia obyczajów, jaß̌ tego pragną Pasterze ludu wiernego.

\section{c) Mitość Boga - główny motyw kultu NSJ w St. Zakonie}

By wszyscy lepiej mogli zrozumieć wartość dowodową tekstów Sta.rego i Nowego Załonu, które teologowie łączą z tym kultem, trzeba najpierw znać przyczyny, dlatego Kościól otacza Boskie Serce Zbawiciela kultem latrii. Dobrze wiecie, Czcigodni Bracia, że te przyczyny są dwojakiego rodzaju. Jest jedna przyczyna wspólna dla wszystkich części ciała Jezusa Chrystusa, wynikająca z faktu, że Serce jako część najszlachetniejsza ludzkiej natury, jest hipostatycznie złączone z Osobą Słowa Bożego, i dlatego zasługuje na kult, którym Kościół darzy Osobę sameg॰ Syna Boga wcielonego. Chodzi tu o prawdę wiary katolickiej, ogłoszoną uroczyście na Soborze ekumenicznym w Efezie i na Soborze drugim Konstantynopolitańskim ${ }^{15}$ ). Druga przyczyna odnosi się szczególniej do Boskiego Serca Zbawiciela i w szczególniejszy sposób do-maga się dla niego kultu latrii, a to dlatego, że Serce Jego, więcej niż inne części ciała, jest naturalnym wskaźnikiem i symbolem Jego miłości dla rodu ludzkiego. Poprzednik Nasz, Leon XIII głosił: ,W Sercu Jezusa jest symbol i obraz nieskończonej miłości Jezusa Chrystusa, która nas porusza do miłości wzajemnej"16).

Wiemy, że Pismo święte nie podaje żadnej osobnej wzmianki o spejako symbolu Jego miłości. Jeśli taki stan rzeczy otwarcie stwierdzamy, to dodajmy, że nie budzi w nas ani podziwu ani wątpliwości fakt inny, cjalnym kulcie czci i miłości dla fizycznego Serca Słowa Wcielonego to mianowicie, że Miłość Boża, która jest racją zasadniczą tego kultu, bywa w St. i w Nowym Zakonie'w takich obrazach przedstawiana, które nas głęboko wzruszają. Obrazy te w Piśmie świętym podawano, by zapowiadały przyjście Syna Bożego w postaci człowieka, mogą wię:

14) Is. $12,3$.

15) Conc. Ephes. can. 8; cfr. Mansi, Sacrorum Conciliorum Ampliss. Collectio, 4, 1083 C.; Conc. Const. 2, can. 9; cfr. ibid. 9, 382 E.

${ }^{16}$ ) Cfr. Enc. Annum sacrum: Acta Leonis. vol. 19, 1900, p. 76. 
być rozważane jako znaki tej Boskiej miłości i zapowiedzi kultu Bo-. skiego Serca Zbawiciela.

Dla naszego celu nie ma potrzeby mnożyć cytaty ze Starego Zakonu. kióre zawierają prawdy Boże dawniej objawione. Sądzimy, że wystarczy przypomnieć Przymierze zawarte pomiędzy Bogiem i ludźmi, uświęcone pokojowymi ofiarami. Zasadnicze prawa tego Przymiecza podał Mojżesz rzeźbione na dwóch tablicach ${ }^{17}$ ), następnie objaśniali je Prorocy. Fakt ten potwierdzono nie tylko węzłami uznania najwyższej władzy Boga i należnego $\mathrm{Mu}$ posłuszeństwa, a został poparty także racjami wyższymi miłości stałej i trwałej. Bo także dla ludu Izraelskiego najwyższą przyczyną posłuszeństwa Bogu był nie strach przed karami i zemstą Boga, grożącego piorunami i grzmotami z Góry Synaj. ale miłość należna Bogu: „Słuchaj, Izraelu, Pan, Bóg nasz, Pan jeden jest. Będziesz miłował Pana Boga twego ze wszystkiego serca twego i ze wszystkiej duszy twojej i ze wszystkich sił twoich. I będą te słowa, które ja dziś przykazuję tobie, w sercu twoim“" ${ }^{18}$ ).

Wobec tego nie dziwmy się, że Mojżesz i Prorocy (słusznie Doktor Anielski nazywa ich ,starszymi“ ludu wybranego) ${ }^{19}$ ) rozumiejąc, że fundamentem całego Prawa było przykazanie miłości, opisywali stosunki pomiędzy Bogiem i narodem wybranym przy użyciu podobieństw wziętych raczej z wzajemnej miłości pomiędzy ojcem i dziećmi, miłości pomiędzy małżonkami ,niż srogich obrazów natchnionych władzą Boga-Pana-Władcy, lub pełną strachu zależnością niewolniczą nas wszystkich od Boga. Wspomnijmy bodaj dla przykładu, jak to IVIojżesz układając swoją przesławną pieśń o wyzwoleniu ludu z niewoli egipskiej, gdy chciał wyrazić, że było to dzieło pomocy Boga wszechmocnego, używa takich wzruszających słów i obrazów: „Jako orzeł wywahiający ku lataniu orlęta swe i nad nimi latający, rozszerzył skrrydła swe (Pan) i wziął Izraela i nosił na ramionach swoich ${ }^{20}$ ). Ale może najlepiej akcentuje miłość prorok Ozeasz, gdy mówi o Bogu, który w każdej chwili pomaga ludowi. W pismach tego proroka, który wścod proroków ,mniejszych" wyróżnia się głębią pojęć i ścisłością określeń, czytamy, że Bóg objawia ludowi vybranemu miłość pełną sprawiedliwości i troskliwości, podobną do miłości ojca miłosiernego, albo do miIości oblubieńca, którego miłość ciężko urażono. Ozeasz mówi o miłości, która nie pomniejsza się ani nie ustaje wobec perfidii i zdrady i straszliwych zbrodni, nie zsyła kary zasłużonej dlatego tylko, by củdzołożną oblubienice i dzieci nieposłuszne nawrócić, oczyścić, odnowić i na nowo połączyć ze sobą węzłami miłości: „Ponicważ Izrael był dzieckiem, i umiłowałem go i z Egiptu wezwałem syna mego... A ja jako piastun Efraima, nosiłem ich na ramionach moich a nie wiedzieli, że troszczyłem się o nich... Powrozami Adamowymi pociągnę ich,

\footnotetext{
17) Cfr. Ex. 34, 27-28.

15) Deut. 6, 4-6.

19) Sum. Theol. 2-2, q. 2, a. 7; ed. Leon. tom, 8, 1895, p. 34.

20) Deut. $32,11$.
} 
więzami miłości... Zleczę rany ich, umiłuję ich, bo się odwróciła zapalczywość moja od nich. Będę jako rosa, Izrael zakwitnie jako lilia i puści się korzeń jego jako Libanu“" 21).

Podobne wypowiedzi znajdujemy także u Proroka Izajasza, gdy przedstawia jakoby rozmowę Boga z ludem wybranym: „Syjon mówił: Opuścił mnię Pan i zapomniał o mnie - izali może zapomnieć niewiasta niemowlęcia swego, aby się nie zlitowała nad synem żywota swego? A choćby ona zapomniała, wszakże ja nie zapomnę o tobie“" ${ }^{22}$ ). Nie mniej wzruszające są słowa Pieśni nad pieśniami, gdzie autor używa porównań z miłości małżeńskiej i wymownie opisuje węzły wzajemnej miłości, łączące Boga i umiłovany przeń lud: Jako lilia między cierniami ,tak przyjaciółka moja między córkami. Ja dla miłego mego, a dla mnie miły mój, który się pasie między liliami. Przyłóż mnie jako pieczęc do serca mego, jako pieczęć do ramienia twego, bo mocna jest jako śmierć miłość, twarda jako piekło jest zazdrość, pochodnie jej pochodnie ognia i miłości“" ${ }^{23}$ ).

Ta miłość Boga najczulsza, wybaczająca, cierpliwa, chociaż wreszcie odrzuciła lud Izraela dodający zbrodnie do zbrodni, jednak nigdy go całkowicie nie potępiła, wydaje się nam miłością o najwyższym napięciu i zapowiedzią tej miłości, którą obiecany ludzkości Zbowiciel z najmilszego Serca swego wylał na nas wszystkich i która stała się fundamentem Nowego Testamentu. Prawdą jest, że prawdziwy, Jednorodzony Syn Boży, Słowo, które stało się ciałem, Jezus, „pełen łaski i prawdy" ${ }^{24}$ ) przyszedł do ludzi, obarczonych grzechami i winami, że tylko On, z ludzkiej swej natury, hipostatycznie złączonej z Osobą Boską, mógł rodzajowi ludzkiemu otworzyć ,źródło wody żywej“, które by zrosilo wyschłą ziemię i zmieniło ją w ogród kwitnący i owocujący. U Proroka Jeremiasza znajdujemy zapowiedź tego niezwykłego cudu, zdziałanego przez odwieczne miłosierdzie i miłość Bożą: „Miłością wieczną umiłowałem Cię, dlatego przyciągnąłem cię, litując się... To będzie przymierze, które zawrę $\mathrm{z}$ domem Izraelowym po onych dniach, mówi Pan, położę zakon mój we wnętrznościach ich i na sercu ich zapiszę go, a będę im Bogiem, a oni będą mi ludem... bo się zlituję nad ich nieprawościami, a grzechów ich więcej nie wspomnę" ${ }^{25}$ ).

\section{Kulı NSJ w świetle $\mathbf{N}$. Testamentu i Tradycji}

\section{a) miłość Boga we Wcieleniu i Odkupieniu}

Dopiero z Ewangelii poznajemy dokładnie, czym jest Nowe Przymierze zawarte pomiędzy Bogiem i ludźmi. Zapowiedziane przez Jeremiasza przymierze zawarte pomiędzy Bogiem i ludem Izraelskim za

21) Cs. 11, 1, 3-4; 14, 5-6.

22) Is. $49,14-15$.

23) Cant. 2,$2 ; 6,2 ; 8,6$.

24) Jo. 1, 14.

25) Jer. 31,$3 ; 31,33-34$. 
pośrednictwem Mojżesza - było tylko symbolem i obrazem tego nowego Przymierza, właściwego, dokonanego przez Słowo Wcielone. To przymierze jest niezrówanie wyższe, wznioślejsze, trwalsze, zawarte nie we krwi kozłów i wolów, ale potwierdzone święta krwią, „Baranka Bożego który gładzi grzechy świata" ${ }^{26}$ ). Przymierze chrześcijańskie wyraźniej niż stare przymierze wykazuje, że oparte jest nie na niewolnictwie i strachu, ale na przyjaźni, jaka łączy ojca z dziećmi. To nowe przymierze wzmacniają i żywią łaski Boże i natchnione jest prawdą, wedle słów Ewangelisty: ,Z pełności Jego wszyscyśmy wzięli łaskę za łaskę. Albowiem Zakon, Prawo - dany jest przez Mojżesza, a łaska i prawda stały się przez Jezusa Chrystusa" ${ }^{27}$ ).

Te słowa ,Ucznia, którego umiłował Jezus, który w czasie Wieczerzy złożył głowe na piersi Zbawiciela“"28), wprowadzają nas w tajemniç nieskończonej Miłości Słowa Wcielonego. Godną jest przeto rzeczą, sprawiedliwą, słuszną i zbawienną, Czcigodni Bracia, byśmy się njeco zatrzymali w kontemplacji najmilszej tej tajemnicy. Oświeceni światłością Ewangelii będziemy mogli osiągnąc to, o czym pisze Apostoł do Efezian: ,by przez wiare Chrystus zamieszkał w sercach naszych, umocnił nas i ugruntował w miłości, abyśmy wraz ze wszystkimi świętymi mogli pojąć, jaka ona jest rozległa i daleka, wzniosła i giẹboka — abyśmy też mogli poznać, jak miłość Chrystusa przewyższa wszelką wiedze i tak byli napelnieni pełnością Boga" 24).

Boska Tajemnica Odkupienia jest przede wszystkim z natury swej, tajemnicą miłości, miłością sprawiedliwą Chrystusa wobec Ojca w niebiesiech. Ofiara Krzyża złożona z miłością i pokora przyniosła nieskończone wynagrodzenie należne za grzechy rodu ludzkiego: „Chrystus złożył ofiarę z miłości i posłuszeństwa i tak dał Bogu wiẹcej, niż wymagało naprawienie winy całego rodzaju ludzkiego"30). Jest to więc dzieło miłosierdzia i miłości Trójcy świętej i Boskiego Odkupiciela względem wszystkich ludzi, którzy sami nie mogli dostateeznie odpokutować swoich grzechów ${ }^{31}$ ). Przez przeobfite bogactwo swoich zasług, zdobytych wylaniem Krwi swej przenajdroższej, mógi Chrystus odnowić i naprawić przymierze przyjaźni pomiẹdzy Bogiem i ludźmi, zerwane niegdyś przez nieszczęsny upadek Adama w raju, nastẹpnie przez niezliczone grzechy ludu wybranego. Boski Zbawiciel, nasz prawowity i doskonały Pośrednik, przez swoją wielka miłość wyrównał długi i zobowiązania rodu ludzkiego wobec praw Bożych, sprawił przedziwne pojednanie pomiędzy Bożą sprawiedliwością i Bożym miłosierdziem, a tajemnica naszego zbawienia wzniosła się ponad wszystko, jak o tym rozprawia Doktor Anielski: ,Stwierdzamy, że wyzwolenie

\footnotetext{
26) Cfr. Jo, 1, 29; Hebr. 9, 18-28; 10, 1--17.

2`) Jo. 1, 16--17.

28) Jo. 21, 22.

$\left.{ }^{29}\right)$ Eph. 3, 17-19.

30) Sum. Theol. 3, q. 48, a. 2; ed. Leon. tom, 9, 1903, p. 464.

31) Cfr. Enc. Miserentissimus Redemptor: A. A. S. 20, 1928, p. 170
} 
człowieka przez mękę Chrystusa odpowiadało i miłosierdziu i sprawiedliwości Bożej. Sprawiedliwości, bo przez Mękę Chrystusa zadość uczynił za grzech ludzkości, człowiek przez sprawiedliwość Chrystusa został wyzwolony. Miłosierdzia, - bo człowiek sam nie mógł za siebie wynagrodzic, więc Bóg dał Syna swego, by za nas wynagrodził. Było to dzieło o wiele większego miłosierdzia, niż gdyby Bóg był nam grzechy odpuścił bez zadość uczynienia. Dlatego powiedziano: „Bóg który jest bogaty w miłosierdzie, dla wielkiej miłości swojej, którą nas umiłował, gdybyśmy byli umarłymi przez grzechy, ożywił nas w Chry-

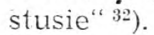

b) potrójna mitość Zbawiciela dla ludzi:

boska, ludzka duchowa i uczuciowo-zmystowa

Byśmy rzeczywiście mogli pojąć, o ile to dla nas śmiertelnych, jest możliwe, „wraz ze wszystkimi świętymi, jaka jest szerokość, długość, wzniosłość i głębia“" ${ }^{33}$ ) tajemnicy miłości Słowa Wcielonego do Ojca w niebiesiech i do grzeszników, trzeba nam rozważyć, że ta miłość była nie tylko duchowa, jak wypada Bogu, jako że Bóg duchem jest ${ }^{34}$ ). Taką duchową miłość żywił Bóg dla naszych przodków, dla ludu hebrajskiego. Spotykane w Psalmach, w pismach Proroków, w Pieśniach nad pieśniami wypowiedzi o miłości odnoszą się do najprawdziwszej, ale duchowej miłości Boga dla ludzi. Ale opisy miłości w Ewangelii, w pismach Apostolskich, w Apokalipsie odnoszące się do miłości Serca Jezusowego, nie oznaczają samej tylko miłości Bożej, ale także miłość ludzką. To wszystko jest dla prawdziwych katolików całkiem jasne.

Słowo Boże nie przyjęło jakiegoś ciała pozornego, jak to w pierwszym wieku głosili niektórzy heretycy, potępieni przez Apostoła Jana: „Bo wielu zwodzicieli zjawiło się na świecie, którzy nie uznają, że Je.zus Chrystus przyszedl w ciele. Kto tak glosi, zwodzicielem jest i Antychrystem" "35). Słowo Boże przyjęło nature ludzka, osobową, całą i doskonała, poczętą w przeczystym łonie Maryji Dziewicy ze sprawą Ducha Świętego (Łk. 1, 35), i włączyło ją do swej Boskiej Osoby. Przyjęło ją całkowicie, nie pomniejszoną nie odmienioną co do duchá i ciała, obdarzoną inteligencją i wolą i innymi zewnętrznymi własnościami poznania, zmysłów, popędów naturalnych. Tak o tym uczy Kościól katolicki wedle zasad uroczyście uznanych i potwierdzonychi, przez Papieży Rzymskich i Sobory Powszechne: "Totus in suis, totus in nostris" = cały jako Bóg, cały jako człowiek, doskonały w Bóstwie, doskonały W człowieczeństwie ${ }^{37-3 \$-39}$ ), "totus Deus homo, totus homo Deus".

32) Eph. 2, 4; Sum. Theol. 3, q. 46, a. 1 ad 3; ed Leon, tom, 9, 1903. p. 436 .

33) Eph. 3, 18.

34) Jo. 4, 24.

35) 2 Jo. 7.

:36) Cfr. Luc. 1, 35.

$\left.{ }^{37}\right)$ S. Leo Magnus, Epist. dogm. ..Lectis dilectionis tuae" ad Flavianum Const. Patr. 13 Iun. a. 449; cfr. P. L. 54, 763. 
Nie można więc wątpić, że Jezus Chrystus miał prawdziwie Ciało, ze wszystkimi ciała właściwościami, wśród których najwyższa jest miłość. Nie można wątpić, że miał także serce fizyczne, naszemu podobne, bo bez tej najwspanialszej części ciała, życie ludzkie nie mogłoby istnieć, także jeśli chodzi o uczucia. Serce Jezusa złączone hipostatycznie z Boską osobą Słowa pod wpływem miłości i innych uczuć niewątpliwie ulegało poruszeniom, a poruszenia te, uczucia, zgadzały się i z ludzką wolą, pelną miłości Bożej, i z samą nieskończoną miłością, która Syna łączy z Ojcem i Duchem Świętym, tak że nigdy nie było tam żadnego sprzeciwu pomiędzy trzema rodzajami miłości ${ }^{40}$ ).

Słowo Boże przyjęło naturę ludzką, prawdziwie, doskonale ludzką, uformowało sobie serce cielesne, które podobnie jak nasze, może cierpieć, być przebite, zranione. To wszystko trzeba rozważyć w świetle polącznia hipostatycznego i substancjalnego, w świetle odkupienia, bo inaczej pojęte może być dla wielu zgorszeniem i głupstwem, jak było z Chrystusem w stosunku do żydów i pogan ${ }^{41}$ ). Dogmaty wiary katolickiej zgodnie z Pismem świętym uczą nas, żc Syn Boży dlatego przyjął naturę lucizką uległą cierpieniom i śmierci, bo pragnął złożyć krwawc ofiare na krzyżu i tak dokonać zbawienia ludzi. Tak to wyjaśnia Apostoł narodów: „Albowiem tak ten, który uświęca, jak i ci, co uświęcenia dostępują, z jednego pochodzą wszyscy. I dlatego nie wstydzi się nazywać ich braćmi, mówiąc: imię twoje ogłoszę braciom moim oto ja i dzieci moje, które mi dal Bóg. Skoro jednak dzieci w ciele i krwi uczestniczą, podobnie i on stał się uczestnikiem, dlatego musiał we wszystkim upodobnić się do braci, aby stać się miłosicrnym i wiernym najwyższym kapłanem przed Bogiem dla przebłagania za grzech ludzi. Bo w czym sam cierpiał i był doświadczany, mocen jest dopomóc i tym, którzy doświadczeń doznają“" ${ }^{42}$ ).

\section{c) Ojcowie święci o uczuciach Stowa Wcielonego}

Ojcowie święci, wiarygodni świadkowie Boskiego Objawienia, dobrze zrozumieli, co już św. Paweł wyraźnie uczył, że tajemnica Boskiej Miłości jest niejako podstawą, zasadą i szczytem Wcielenia i Odkupienia. Spotykamy bowiem u nich częste i obszerne wzmianki o tym, że Jezus dla tego przybrał nature ludzką i nasze ułomne ciało, by mógł działać dla naszego zbawienia, by mógł nam jak najwyraźniej objawić swoją nieskończoną miłość także zewnętrznie.

Justyn święty pisze jakby echo słów Apostoła narodów: „Miłujmy

${ }^{38)}$ Conc. Calced. a. 451; cfr. Mansi, Op. cit. 7, 115 B.

${ }^{39}$ ) Gelasius Papa, Tract. 3: "Necessarium" de duabus naturis in Christi cfr. A. Thiel, Epist. Rom. Pont. a S. Hilaro usque ad Pelagium 2, p. 532.

40) Cfr. S. Thom. Sum. Theol. 3, q. 15, a. 4; q. 18, a. 6: ed Leon. tom 11, 1903, p. 189 et 237.

41) Cfr. 1 Cor. 1, 23.

$\left.{ }^{42}\right)$ Hebr. 2, 11-14; 17-18. 
i czcijmy urodzone z niezrodzonego Boga Słowo, bo dla nas stało się człowiekiem, by stawszy się uczestnikiem naszych ludzkich cierpień, dał nam lekarstwo na te cierpienia“"43). Bazyli pierwszy z trzech Ojców Kappadockich, uczy, że uczucia zmysłowe Chrystusa były prawdziwie ludzkie i zarazem święte. „Pan nasz przyjął naturaine uczucia na dowód prawdziwego, nie fantastycznego wcielenia, ale odrzucił uczucia grzeszne, które psują czystość naszego życia, jako niegodne boskiej nieskalaności“" $\left.{ }^{44}\right)$. Chluba i sława Kościoła Antiocheńskiego, św. Jan Chryzostom, mówił, że uczucia, które objawiał Jezus, jasno potwiecdzają, że Chrystus przyjął prawdziwie i całkowicie ludzką naturę: „Jeśliby bowiem nie miał naszej natury, nie byłby przeżywał naszych smutków i płakał" ${ }^{45}$ ).

Z pośród Ojców łacińskich trzeba tu tych wspomnieć, których Kościół dzisiaj czci jako swoich najgłówniejszych Doktorów. Sw. Ambroży widzi w unii hipostatycznej naturalne źródło uczuć i wzruszeń zmysłowych, które przeżywało Słowo Boże, gdy stało się człowiekiem: „Dlatego, że przyjął także uczucia duszy, bo inaczej Bóg, jako że jest Bogiem, nie mógłby się smucie ani umierać“ $\left.{ }^{46}\right)$. Z tych właśnie uczuć św. Hieronim wyprowadza główny dowód na tezę, że Chrystus rzeczywiście przyjął ludzką naturę: „Pan nasz, by wylkazać prawdziwość przyjętego człowieczeństwa, prawdziwie przeżywał smutek" ${ }^{47}$ ). Św. Augustyn z wlaściwym sobie naciskiem podaje zależnośći, jakie zachodzą pomiędzy uczuciami Słowa Wcielonego, a celem ludzkiego Odkupienia: ,Te uczucia ludzkiej słabości, słabe ciało ludzkie, śmierć tego ciała przyjął Pan nasz nie z konieczności, ale z miłosierdzia, aby przemienił w Sieb:e ciało swoje, to jest Kościół, którego chciał być głową, to jest przyjąi członki swoje w świętych i wiernych. Gdyby któremus z nich wypadło smucić się i cierpieć, nie uważał siebie dlatego za pozbawionego łaski, że to nie są grzechy ale oznaki ludzkiej słabości i ułomności. Tak Ciało mistyczne Chrystusa poniekąd staje się podobne do chóru różnych głosów, które włączają się do golsu intonującego, zaczynającego śpiew, czyli członki idą za głosem Glowy tego Ciała" ${ }^{43}$ ). Zwiężlej, ale nie mniej trafnie o tych sprawach mówi św. Jan Damascenski: „Całego mnie cały przyjął, caly złączony jest z calościa, by całości przynieść zbawienie. Inaczej nie mogło by być uzärowione co nie było by przyjęte“49). "Wszystko więc przyjąl, by wszystko uświę$\operatorname{cic}^{i(50)}$.

43) Apol. 2, 13; P. G. 6. 465.

${ }^{44)}$ Epist. 261, 3: P. G. 32, 972.

${ }^{45)}$ In Joann. Homil. 63, 2; P. G. 59, 350.

46) De fide ad Gratianum, 2, 7, 56; P. L. 16, 594.

$\left.{ }^{47}\right)$ Cfr. Super Matth. 26, 37; P. L. 26, 205.

$\left.{ }^{48}\right)$ Enarr. in Ps. 87, 3; P. L. 37, 1111.

49) De Fide Orth. 3, 6: P. G. 94, 1006.

50) Ibid. 3, 20: P. G. 94. 1081.

Ruch Eibijiny i Liturgiczny - II. 


\section{d) Symbolizm naturalny Serca Jezusa w wypowiedziach Pisma świętego i Ojców Kościoła}

Przyznać trzeba, że te wypowiedzi Pisma świętego i Ojców wyżej: podane $i$ wiele innych podobnych, tu nie podanych, chociaż wiele mówią o tym, że Jezus przyjął ludzką naturę i ulegał ludzkim uczuciom, by nas zbawić, nigdy jednak tych uczuc nie przypisuja jego fizycznemu Sercu, nie wskazują wyraźnie tego Serca, jako symbolu miłości nieskończonej. Chciaż ewangeliści i inni święci pisarze, wprost nie opisują Serca naszego Zbawiciela, obdarzonego nie mniej niż nasze zdolnością odczuwania, bijącego uczuciami podwójnej woli jego najgorętszej miłości, to jednak wyraźnie wskazują jego Boską miłośé i uczucia z niej wynikające, pragnienia, pożądania, radość, smutek, obawy, gniew, jakie okazują się w słowach i gestach Jezusa.

Przede wszystkim w obliczu Zbawiciela, jakby w zwierciadle odbijają się najwierniej uczucia, które wzruszały umysł i wolę, jakby fale odbijają się o drugi brzeg, wracają do Najświętszego Jego Serca, powodują wzruszenia. Do tej sprawy odnosi się wypowiedź Doktora Anielskiego, jako wynik powszechnego doświadczenia i znajomoścı psychologii ludzkiej: ,Zamieszanie wskutek gniewu okazuje się aż na zewnątrz, uwidocznia się w tych członkach, w których wyraźniej przejawia się wpływ serca, w oczach, twarzy, w języku“"51).

Slusznie więc Serce Słowa Wcielonego jest uważane za główny wskaźnik i symbol tej potrójnej miłości, którą Boski Zbawiciel stale miłuje Ojca przedwiecznego i wszystkich ludzi. Serce to jest symbolen miłości Syna z Ojcem i z Duchem Swiętym, tej miłości, która jedynie w nim tylko, w Słowie, ktore stało się cialem, objawiło się w ludzkim słabym ułomnym ciele, chociaż ,w nim przebywa wszelka pełność bóstwa cieleśnie“"5*). Jest ono także symbolem miłości płomiennej, wlanej w duszę Chrystusa, wzbogacajacej jego wolę. Czyny Chrystusa są oświecone i kierowane podwójną wiedzą, błogosławioną i wlaną" 53. W sposob jeszcze bardziej naturalny i bezpośredni, jest wreszcie Serce Jezusa symbolem jego miłości wyrażonej na zewnątrz, gdyż ciało Zbawiciela, uformowane w najczystszym łonie Dziewicy Maryji przez wpływ przedziwny Ducha świçtego, przewyższa w doskonałości, a więc i w zdolności odbiorowej każdy inny organizm ludzki ${ }^{54}$ ).

Wypowiedzi Pisma Świętego i wywody wiary katolickiej ucza, ̇e w najświętszej duszy Jezusa Chrystusa wszystko było w najwyższej zgodzie i harmonii. Jezus kierował swoją potrójną miłość wyraźnie do zdobycia naszego Odkupienia. Mamy więc najsluszniejsze powody do tcgo, by na Scrce Jezusa patrzeć jako na najwymowniejszy obraz Mi-

\footnotetext{
${ }^{61)}$ Sum. Theol. 1--2, p. 48 a. 4: ed Leon. tom, 6, 1891, p. 306.

5) Col. 2. 9.

53) Cfr. Sum. Theol. III, q. 9, aa. 1-3; ed. Leon. tom. 11, 1903, p. 142.

${ }^{54}$ Cfr. Ibid. 3, q. 33, a. 2, ad 3 m; q. 46, a. 6; ed. Leon. tom. 11, 1903,
} pp. 342, 433. 
łości Boskiego Zbawiciela, czcić w Nim świadka naszego Odkupienia, widzieć w Nim jakby mistyczne schody, którymi wstępujemy ,w objęcia Boga naszego Zbawiciela"55). Będziemy więc podziwiać i wysławiać Jego miłość objawiającą się w różnych dziełach i czynach, słowa i czyny, przykazania, cudy, a zwłaszcza te dzieła, które nam więcej objawiają miłość Jego Serca, jako to Boskie ustanowienie Eucharystii, ciężką i bolesną męlkę i śmierć na krzyżu, danie nam IVatki Najświętszej, założenie Kościoła, zesłanie Ducha świętego na Apostołów i na nas. Nabożnie i z miłością będziemy rozważać uderzenia Boskiego Serca, którymi jakby ocimierza przebieg czasu na ziemi aż do tej chwili najwyższej, gdy jak Ewangelista zaświadcza, ,wołając głosem wielkim powie: "Wykonalo się - i skłoniwszy głowę odda ducha“" ${ }^{56}$ ). Ustało bicie Serca, ustała na chwilę miłość zmysłowa, aż Chrystus zwycięży śmierć i wstanie z grobu. Gdy zaś Jego ciało, osiągnąwszy stan chwały wiecznej, znowu złączylo się z duszą Boskiego Zbawiciela, Serce Najświętsze już nigdy nie przestalo bić spokojnym miarowym rytmem, nigdy nie przestanie wyrażać swojej potrójnej miłości, którą Syn Boży kączy się ze swoim Ojcem w niebiesiech i z całą ludzkością, której sam jest pełnoprawną głową mistyczną.

\section{Aktywny udzial NSJ w zbawezej misji Odkupiciela}

a) Serce Jezusa symboler milości Jezusa w czasie ziemskiego życia Zbawiciela

Teraz. Czcigodni Bracia, chcielibyśmy obfitsze zebrać owoce z tych radosnych rozważań, dlatego w kontemplacji rozważmy uczucia ludz-kie i boskie naszego Zbawiciela i jego Serca, podczas ziemskiego Jego życia i w dalszym życiu aż do wieczności. Zażądamy przede wszystkin od Ewangelii świałła, umożliwiającego nam wejście do świątyni Boskiego Serca, w której wraz z Apostołem narodów podziwiac bęaziemy „niezmierne bogactwa łaski (Bożej) w łaskawości dla nas Chrystusa .Jezusa" 57 ).

Uwielbienia godne Serce Jezusa bije miłością ludzka i boską od chwili, gdy IVaryja wyrzekia owe wielkoduszne: „Fiat - niech mi sic stanie!“ Słowo Boże „wychodzạc na świat mówi: Nie chciałeś ofiary i daru, aleś mi stworzył ciało. W całopaleniach za grzechy nie upodobałeś sobie. Wtedy rzekłem: Oto idę, jak napisano o mnie na poczatku księgi, abym speinił, o Boże, wolę Twoją". Wedle Twojej woli uświeceni jesteśmy ofiarą Ciała Chrystusa raz na zawsze" "s).

Miłością biło Serce Zbawiciela, zgodną uczuciami ludzkimi i miłościa Boska, gdy w domu Nazaretańskim rozmowy prowadził Jezus ze

55) Tit. $3,4$.

56) Matth. 27, 50; jo. 19, 30.

57) Eph. 2, 7.

${ }^{58)}$ Hebr. 10, 5-7. 10. 
swoja najmilsza Matką, z domniemanym ojcem Józefem, któremu posłusznie i pracowicie pomagał $\mathrm{w}$ pracach ciesielskich. Tymi potrójnymi uczuciami kierował się Jezus w codziennych swoich wędrówkach w czynieniu cudow niezliczonych, gdy wskrzeszał umariych, wracal zdrowie chorym, wykonywał różne prace, znosił głód i pragnienie, męczył się i pot wylewał, noce spędzal na czuwaniu i modlitwie do Ojca w niebiesiech, gdy głosił mowy i przypowieści, te zwłaszcza o milosierdziu, o zgubionej drachmie, zgubionej owcy, synu marnotrawnym. W tych wszystkich słowach i dziełach ukazuje się wyraźnie Serce Zbawiciela, wedle słów Grzegorza Wielkiego: „Ucz się Obecności Serca Jczusa w słowach Bożych, byś tym goręcej wzḋychał do rzeczy wyższych" ${ }^{0}$ ).

Serce Jczusa wydatniejszą okazywało miłość, gdy z ùst Jego wychodzily słowa większej miłości. Wspomnijmy tu dla przykiadu chwilę, gdy Jezus widzial znudzone rzesze ludu, głodne, utrudzone, i gdy zawołał: „Zal mi tego ludu“60). Gdy patrzył na umiłowane swoje miasto, zaślepione w grzechach, zagrożone ruiną i wołał: Jeruzalem, Jeruzalem, które zabijasz proroków i kamienujesz tych, którzy są do ciebie posłani - ilekroć chciałem zgromadzić syny twoje, jako kokosz gromadzi swoje kurczeta, a nie chciałoś" ${ }^{61}$ ). Miłością do Ojca i świętym oburzeniem biło to Serce, gdy widział świętokradzkie kupczenie w świątyni i piętnował świętokradzców tymi słowy: „Napisane jest: dom mój jest domem modlitwy, a wyście uczynili go jaskinią zbójców" ${ }^{62}$ ).

Szczególnicjszą miłością i trwogą biło Serce Jezusa, gdy nadchodziły chwile męki straszliwej. Naturalna zgroza, wstręt, strach przed męką i śmiercią wywołały okrzyk: Ojcze, jeśli można, niech odejdzie odo mnie ten kielich cierpienia" ${ }^{63}$ ). Zwycięska miłość i wielka gorycz napełniała Serce Jezusa, gdy przyjmował zdradziecki pocałunek i ostatnią czynił próbę, by nawrócić przyjacicla i zdrajcę, trwającego w ślepym uporze: „Przyjacielu, po coś przyszedł? Pocałunkiem zdradzasz niewiast, gdy płakały nad niezasłużoną kaźnią krzyżową Zbawiciela: Syna człowieczego?" $\left.{ }^{64}\right)$. Z wielką miłością i współczuciem mówil do ,Córki Jerozolimskie, nie płaczcie nade mną, ale nad wami samymi i. nad synami waszymi - bo jeśli to czynią z drzewem zielonym, cóż zo suchym się stanie?" $\left.{ }^{65}\right)$.

Gdy Boski Zbawiciel zawisł na krzyżu, Serce Jego przepelniły różne uczucia: płomienna miłość, przygnębienie, przerażenie, miłosierdzie, litość, błogi pokój, a świadkami tych uczuć są tak wymowne słowa: "Ojcze, odpuść im, bo nie wiedzą, co czynią" $\left.{ }^{66}\right)$, Boże mój, Boże mój,

\footnotetext{
${ }^{59}$ ) Registr. epist. lib. 4, ep. 31 ad Theodorum medicum: P. L. 77, 706.

${ }^{60}$ ) Marc. 8, 2 .

61) Matth. 23, 37.

82) Matth. 21, 13.

63) ivath. 26, 39.

${ }^{64)}$ Matth. 26, 50; Luc. 22, 48

65) Tun 2328,31 .

66) Lic. $23, \pm 4$. 
czemuś mnie opuścił? ${ }^{67}$ ), Zaprawdę, zaprawdę, dziś jeszcze będziesz ze mną w raju“" ${ }^{68}$ ), Pragnę ${ }^{69}$ ), Ojcze, w ręce Twoje oddaję ducha mego: 70 ).

\section{b) dary Serca Jezusowego najwyższe}

Któż zỏola godnie opisać te uderzenia Serca Jezusowego, te znaki nieskończonej Jego miłości, gdy ludziom udzielał darów najwyższych, siebie dawał w Eucharystii, gdy nam dawał Matkę Najświętszą i udzielał Kapłaństwo?!

Zanim Jezus spożył ostatnią wieczerzę z uczniami swoimi Serce Jego już przeżywało wielkie wzruszenia, gdyż Jezus wiedzial, że bẹdzie ustanawiał Sakrament Ciała i Krwi swojej, tej Krwi, którą miał być zatwierdzony i konsekrowany Nowy Testament. Jezus wtedy mówit: „Gorąco pragnąłem pożywać tę Paschę $z$ wami, zanim cierpieć będę" ${ }^{71}$ ). Wzruszenie doszlo do szczytu, gajy Jezus ,wziąwszy chleb W ręce, dzięki czynił, łamał, dał im mówiąc: To jest ciało moje, które za was jest wydane, to czyńcie na moją pamiątkę. Podobnie i kielich, po wieczerzy mówiąc: Ten jest kielich, Nowy Testament we Krwi mojej, która za was przelana będzie" ${ }^{72}$ ). Słusznie więc możeny twier.dzić, że Boska Eucharystia, jako sakrament udzielony ludziom, i jako Ofiara, którą sam dalej składa wiecznie ,od wschodu aż do zachodu" ij), oraz Kapłaństwo są darami Boskiego Serca Jezusa. Darem najcenniejszym, jak już powiedzieliśmy̆, jest także Maryja, IVatka Boża, umiłowana Matka nas wszystkich. Była ona IMatką Zbawiciela co do ciała, towarzyszką Jego w udzielaniu dzieciom Ewy życia łaski Bożej, siusznie więc pozdrawiamy ją jako duchową INatkę całego rodzaju ludzkiego. Tak pisze o tym święty Augustyn: ,Zaiste jest matką cziłonków Zbawiciela, którymi my jesteśmy, bo współdziałała miłością, by ảla Kościoła rodzili się wierni, jako członkowie jej Głowy“"74).

Dał nam siebie, jako dar niekrwawy pod postaciami chleba i wina, aie chciał także Zbawiciel dać szczególniejszy dowód głębokiej, nieskończonej miłości przez krwawą Ofiarę krzyża. Sam przecież uczniom tak mówił o miłości: „Większej nad tę miłość nie ma żaden, jedno ten, kto-duszę swoją położył za przyjaciół swoich" $\left.{ }^{75}\right)$. Dlateg’o Ofiara na Golgocie najwymowniej przedstawia nam miłość Jezusa Chrystusa dla Boga: „Przez to poznaliśmy miłość Boga, że oddał za nas życie swoje i my powinniśmy życie oddać za braci“"76). Boski Zbawiciel w rzeczy-

(67) Matth. 27, 46.

(i8) Luc. $23,43$.

69) Jo. 19, 28.

70) Luc. 23, 46.

i1) Luc. $22,15$.

72) Luc. $22,19-20$.

73) Mal. 1, 11.

${ }^{74)}$ De Sancta virginitate, 6; P. L. 40, 399.

75) Jo. 15, 13.

76) 1 Jo. $3,16$. 
wistości był do krzyża przybity raczej przez miłość swoją dla nas, niż przez katów. Jego dobrowolna ofiara jest najwyższym darem danym ludziom według krótkiego, zwięzłego słowa Apostoła: „Umiłował mnie i dał siebic za mnie ${ }^{67}$ ).

Nie ulega więc wątpliwości, że Serce Jezusa jest w najgłębszy i bezpośredni sposób złączone z Życiem Słowa Wcielonego i tak stało się niejako narzędziem Bóstwa więcej niż wszystkie inne cząstki ludzkiej natury jezusa, i wobec tego stało się także prawowitym symbolen niezmierzonej onej miłości, która skłoniła Zbawiciela, że przez przelanie Krwi wszedł jakby w małżeństwo mistyczne z Kościołem: „Cierpiał z miłości za Kościół, żeby go połączyć ze sobą jako oblubienicę" "). Kościół zrodził się z rany Zbawiciela i stał się zarządea Krwi zbawczej, rozdawcą Sakramentów świętych, stąd dzieci Kościola czerpia wyższe życie, jak o tym czytamy w Liturgii świętej: „Ex Corde scisso Ecclesia Christo jugata nascitur - z rany Serca rodzi się Kośció złaczony z Chrystusem - ze Serca rozdajesz łaski“ ${ }^{80}$ ). O tym symbolizmie nicoboym starożytnym Ojcom i pisarzom Kościoła, jako ich ccha pisze Doktor powszechny: ,Z boku Chrystusa wyciekła woda do olmycia, krew dla zbawienia. Krew odpowiada Sakramentowi Eucharystii, woda Sakramentowi Chrztu, który ma moc obmywającą z krwi Chrystusowej" "1). Co się tu pisze o boku Chrystusa o boku zranionym, otwartym przez żołnierza, to należy także powiedzieć o Sercu Jezusa. Lanca żolnierza wnikia aż do serca, by stwierdzić na pewno śmiexć Chrystusa. Rana Serca Jezusa już umarłego, w ciągu wieków staje się żywym obrazem miłości i ofiary dobrowolnie zlożonej, by ludzi odkupić. Chrystus umiłował nas aż do złożenia krwawej ofiary na Kalwarii: , Chrystus umiłował nas i siebie samego za nas wydal na ofiare i hostię, na wonność wdzięczności ${ }^{82}$ ).

c) NSJ - symbol potrójnej mitości w życiu ludzkim $w$ chwale niebiestiej

Gdy nasz Zbawiciel wstapił do nieba i zasiadl po prawicy Ojea w chwale człowieczeństwa uwielbionego, nie przestał miłować Kościoła, Oblubienicy swojej tą samą miłością. Wszedl do nieba, niosąe na ranach swoich rąk, nóg, boku światlane trofea swego potrójnego zwycięstwa: nad szatanem, grzechem i śmiercią. Niósł w Sercu swoim, jak W najcenniejszym skarbcu, niezmierne bogactwa zasług, owoce potrójnego triumfu, by rozdawać je ludzkości odkupionej. O tej radosnej prawázie tak pisze Apostoł narodów: „Wstąpiwszy na wysokość, wy-

ii) Cal. 2, 20 . p. 329 .

is) Cfr. S. Thom. Sum. Theol. 3, q. 19, a. 1: ed. Leon. tom. 11, 1903,

${ }^{79}$ ) Sum. Theol. Suppl. q. 42, a. 1. ud $3 \mathrm{~m}$ : ed. Leon. tom. 12, 1905, p. 81.

$\left.{ }^{80}\right)$ Hymn. ad Vesp. Festi Ssmi Cordis Jesu.

s1) Sum. Theol. 3, q. 66, a. 3, ad 3 m; ed. Leon. tom. 12. 1906, p. 65.

82) Eph. 3, 2. 
wiódł więźniów pojmanych i ludzi darami obdarzył. Ten, który zstąpił, jest tym samym, co wstąpił ponad wszystkie nieba, aby napelnił wszystko" 83 ).

d) dary Ducha Świętego i Serce Jezusa

Dary Ducha świętego udzielone uczniom Jezusa są pierwszym znakiem zezwnętrznym szczodrobliwej miłości Zbawiciela po jego triumfalnym wstąpieniu na łono Ojca. Po dniach dziesięciu Duch św. Pocieszyciel dany nam przez Ojca zstapił na Apostołów zebranych we Wieczerniku, wedle tego co obiecał Jezus podczas ostatniej wieczerzy: „A ja prosić będę Ojca i innego Pocieszyciela da wam, aby pozostał z wami na zawsze“ ${ }^{\mathrm{s}}$ ). Ten Duch Pocieszyciel, jako że jest IMiłością osobową Ojca do Syna i Syna do Ojca, jest przez obu posłany i w postaci ognistych języków daje duszom wielkie bogactwa Bożej Niłości i innych lask niebieskich. To wlanie Bożej Miłości wynika także ze Serca Zbawiciela, ,w którym są wszelkie skarby mądrości i wiedzy ukryte"85). Miłość jest równocześnie darem Serea Jezusa i Jego Ducha, który jest Duchem Ojca i Syna, z którego wywodzi się pochodzenie Kościoła i jego cudowne rozszerzenic się do wszystkich narodów pogańskich, zakażonych przedtem bałwochwalstwem, wzajemną nienawiścią, zepsuciem obyczajów i gwałtami. Ta Boża milość jest najcenniejszym darem Serca Jezusa i Jego Ducha. Ta miłość udzieliła Apostolom i Męczennikom mestwa, dzięki któremu walczyli heroicznic aż do bohaterskiej śmierci, Ewangelię prawdy poświadczali bohaterską śmiercią. Ta miłość dała Doktorom Kościoła siły do wytrwałego studium w wyjaśnianiu i obronie prawd wiary katolickiej. To ona żywiła enoty Wyznawców, pobudzała do tworzenia dzicł pożytecznych i godnych podziwu, stanowiących wielką pomoc w osiaganiu zbawienia wiecznego i zdobywaniu korzyści doczesnych. Ta miłość sprawiła, że Dziewice dobrowolnie i radośnie wstrzymywały się od rozkoszy cielesnych i całkowicie poświęcały się miłości niebieskiego Oblubieńca. $\mathrm{Na}$ cześć i chwałę tej Boskiej miłości, która wypływa ze Serca Jezusowego i wlewa się do dusz wiernych przez Ducha świętego, Apostoł narodów napisał ten zwycięski hymn, głoszący triumf Jezusa Głowy i członków jego Ciała mistycznego, opiewający zwycięstwo ich nad tymi wszystkimi, którzy przeszkadzali wprowadzeniu królestwa miłości: „Któż tedy odłaczy nas od miłości Chrystusowej? utrapienie czy ucisk? głod czy nagość? niebezpieczeństwo, prześladowanie czy miecsz? Ale w tym wszystkim zwyciężamy przez tego, który nas umiłował. Bo jestem pewien, że ani śmierć, ani życie, ani aniolowie, ani potęgi, ani moce, ani rzeczy teraźniejsze, ani przyszłe, ani co wysokie, ani co głębokie, ani żadne stworzenie nie zdoła nas odłączyć od miłości Bożej, która jest w Chrystusie Jezusie, Panu naszym" "56).

\footnotetext{
83) Eph. 4, 8, 10.

107) Jo. 14, 6.

85) Col. 2, 3.

${ }^{86)}$ Rom. 8, 35, 37-39.
} 


\section{e) kult NSJ jest kultem osoby Stowa Wcielonego}

Nic więc nie zabrania nam adorować Serca Jezusa, jako naturalnego i najwymowniejszego symbolu tej niewyczerpanej miłości, która Boski Zbawiciel dotąd płonie dla rodzaju ludzkiego. Chociaż to Serce już nie podlega burzliwym przemianom tego śmiertelnego życia, zawsze jednak żyje i bije, polączone węzłem nierozerwalnym z Boską Osobą Słovva, a z nią i przez nią połączone z Boską jego wolą. Dlatego to Serce Jezusa, pełne Boskiej i ludzkiej Miłości, zasobne w łaski wysłużone przez Mękę i śmierć, staje się źródłem wiecznotrwałym miłości, którą Duch Jego wylewa na członków swego Ciała mistycznego.

Serce więc naszego Zbawiciela jest jakby obrazem Bożej Osoby Słowa, podwójnej natury, Bpżej i ludzkiej. Możemy w nim rozważać nie tylko symbol, ale jakby treść tajemnicy naszego Odkupienia. Gdy adorujemy Serce Jezusa, to w nim i przezeń adorujemy niestworzona milośc Bożego Słowa, a także ludzką miłość i inne uczucia i cnoty, jako że obie miłości skíaniary Zbawiciela do ofiarowania siebie za nas i za cały Kościół, jako swoją Oblubienice, weale slów Apostola: „Chrystus umiłował Kościół i wydał zań samego siebie, aby go uświęcić obmyciem woda w Słowie żywota, by zgotował sobie Kościól pelen chwaly, nic skalany i bez zmazy, bez czegokolwiek, co by mu ujmę przynosiło, ale święty i niepokalany“ ${ }^{87}$ ).

Chrystus umiłował Kościół, dalej miłuje go potrójną miłością, o której mówiliśmy poprzednio, staje się obrońcą Kościoła ${ }^{88}$ ), by laske i miłosierdzie dlan wyjednać u Ojca, ,bo żyje zawsze, aby wstawiać się za nami"s9). Z Jego Serca stale plyną modlitwy ku Bogu za nami i nigdy nie ustają. Jak niegdyś , za życia swego w ciele“" ${ }^{90}$ ), tak teraz jako triumfator w niebie, $z$ niemniejszą skutecznością wstawia się za nami do Ojca, ,który lak umiłował świat, że Syna swego Jednorodzonego dal, by wszelki, który wierzy weń nie zginął, ale miał życie wieczne"9i). Temu Ojcu przedstawia serce swoje żywe, zranione, więlsszą jeszcze płonace miłością, niż gdy bić przestawało zranione włózznią żolnierza rzymskiego: „I dlatego zranione jest (Serce Twoje), byśmy przez ranę widzialną zobaczyli ranę niewidzialną miłości" ${ }^{02}$ ).Nie ulega więc wąłpliwości, że Ojciec niebieski, który własnego Syna nie oszczędził, ale wydał go za nas wszystkich, gdy Go taki Obrońca będzie prosił i taka modlitwą usilną, przebaczy nam i zawsze będzie obfite wylewał strumienie lask Bożych na wszystkich ludzi.

87) Eph. 5, 25-27.

88) Cfr. 1 Jo. $2,1$.

$\left.{ }^{89}\right)$ Hebr. 7, 25.

90) Hebr. 5, 7.

91) Jo. 3, 16.

$\left.{ }^{92}\right)$ S. Bonaventura, Opusc. 10: Vitis mystica c. 3 n. 5; Opera Omnia. Ad Claras Aquas (Quaracchi) 1898, tom. 8, p. 16 ; cfr. S. Thom. Sum. Theol. 3, q. 54, a. 4: ed. Leon. tom. 11, 1903, p. 513. 


\section{Kult NSJ - powstanie kultu i rozwój}

a) poczatki kultu $w$ nabożeństwie do Ran świętych i Męki

Chcielibyśmy teraz, Czcigodni Bracia, przedstawić glówne zarysy tego kultu, jego istotę, bogactwa łask, które przynosi, i jak ten kult wynika z nauki objawionej, jako swego pierwszorzędnego źródła. Dotychczasowe nasze wywody, naświetlone Ewengelią, jak ufamy, wykazały, że kuit NSJ jest zasadniczo kultem Wcielonego Słowa Bożego, kultem miłości Bożej i ludzkiej Jezusa, tej miłości, którą Ojciec i Duch święty żywią ku ludziom grzesznym. Uczy bowiem Doktor Anielski, że to miłość Trójcy Najświętszej jest źródłem odkupienia ludzi, to ona wpływa na ludzką wole Jezusa i Jego Serce, skłania do przelania krwi by nas z niewoli grzechów wybawie ${ }^{94}$ ). , Muszę byé chrztem ochrzczony i jakoż jestem ściśniony dopóki się to nie spełni“"95).

Jesteśmy przekonani, że nasz kult dla miłości Bożej i miłości Serca Jezusa dla człowieka okazywany Sercu zranionemu Ukrzyżowanego, nigdy nie byl zupełnie obcy pobożności wiernych, z tym naturalnie zastrzeżeniem, że ten kult jasno się uwyraźnił i rozszenzył dopiero w czasach niedawno minionych gdy Bóg tę tajemnicę objawił niektórym synom swoim, obdarowanym obfitością darów i łask Bożych i których wybrał za zwiastunów i głosicieli tego kultu. W żadnym okresie dziejów nie brakło w Kościele ludzi Bogu poświęconych, którzy idąc za przykładem Matki Bożej, Apostołów, wybitnych Ojców Kościoła, głosili i praktykowali kult adoracji, dziękczynienia, miłości dla ludzkiej natury Chrystusa, zwłaszcza dla Jego Ran, które zadano ciału cierpiącemu mękę dla naszego zbawienia.

Jakże nie uznać, że słowa ,Pan mój i Bóg mój" 96) wypowiedziane przez Apostoła Tomasza, które niewiernego zmieniły w wierzącego, zawierają $\mathrm{W}$ sobie wyznanie wiary, adorację, miłość, która od zranionej ludzkości ludzkiej natury Zbawiciela wznosi się aż do majestatu Bo-żej osoby?! Chociaż Serce zranione Jezusa zawsze ludzi silniej slkłaniało do uczczenia jego nieskończonej miłości dla rodzaju ludzkiego, chociaż do chrześcijan z każdego okresu dziejów odnosiły się ponickąd prorocze słowa Zachariasza, zastosowane przez Ewangeliste do Ukrzyżowanego: ,Zobacza, kogo przebodli“" ${ }^{97}$ ), — to jednak trzeba przyznać. że kult specjalny do Serca Jezusowego, jako obrazu miłości ludzkiej i boskiej Słowa Wcielonego, rozwijał się powoli i stopniowo.

b) Kult NSJ w wiekach średnich i nastepnych

Gdy jednak zechcemy prześledzić ważniejsze okresy tego kultu w historii pobożności chrześcijańskiej, trzeba najpierw wspomnieć niektóre:

${ }^{93}$ ) Rom. 8, 32.

94) Cfr. Sum. Theol. 3, q. 48, a. 3: ed. Leon. tom. 11, 1903, p. 467.

$\left.{ }^{95}\right)$ Luc. $12,30$.

96) Jo. 20,28

97) Jo. 19, 37; cfr. Zach. 12, 10. 
nazwiska osób, które możnaby uważać za poprzedników tego kultu. W formie prywatnej, ale w stopniu coraz wyższym i szerszym rozwijał się ten kult w łonie niektórych instytutów zakonnych. Podajemy dla przykładu, że dla ustalenia tego kultu i jego rozwoju dobrze zasłużyli się święci: Bonawentura, Albert Wielki, Gcrtruda, Katarzyna Sieneńska, bł. Henryk Suso, Piotr Kanizy, Franciszek Salezy, Jan Eudes. Ten ostatni był autorem pierwszego officium liturgicznego ku czci NSJ. INa prośby biskupow francuskich pierwsze święto ku czci NS.J było dozwolone i obchodzone 20 października 1672 roku. Szczególne miejsce wśród promotorów tego najwznioślejszego kultu zajmuje św. Małgorzala MIaria Alacoque. Przy pomocy swego duchowego przewodnika, bł. Klaudıusza de la Colombiere, przez wytrwałe i wspaniałe swoje wysiłki osiagnęla to, że kult przybrał pewne określone formy i rozwijał sio dobrze wśród entuzjazmu wiernych, że wśród innych form pobożności odznaczał się i wyróżniał duchem miłości i wynagrodzenia ${ }^{98}$ ). Wystar.. czy krótkie wspomnienie owych czasów, byśmy należycic zrozumieli, że swój niezwykły rozwój kult ten zawdzięczał temu, że zgadzał się doskonale $z$ istotą chrześcijańskiej religii, religii miłości. Należy więc stwierdzić, że kult ten nie stąd wziął początek, że przez Boga byi prywatnie objawiony, że nagle zjawił się w Kościele, ale ten kult wyrósł z wiary żywotnej i z gorliwej pobożności, a rozszerzali go ludzie obda-rzeni laskami, mającymi cześć dla Zbawiciela i dla jego chwalebnych ran, osoby, ktore w sposób wymowny przekonywały umysł i porywały serca dla tego kultu. Objawienia św. Małgorzaty Maryji, jak wiemy, nie przyniosły żadnych nowych objawień, nie dodały nowych treści dla nauki katolickiej. Główna ich myśl polega na tym, że Chrystus Pan, okazując swe serce w sposób niezwykły i wyjątkowy, chciał wezwac umysły ludzi do rozważania i czczenia tajemnicy miłości, okazanej ludzhości przez Boga miłosiernego. Przez to szczególniejsze objawienie Chrystus w słowach wyraźnych, kilka razy powtórzonych, wskazał na Serce swoje, jako na symbol, który by zachęcił ludzi do poznania i uznania swej miłości. Zarazem Jezus uczynił to Serce jakby znakiem i porẹczeniem miłosierdzia i łaski dla Kościoła w naszych czasach.

\section{c) aprobata papieska - święto ku czci NSJ}

To, że ten kult wynika z zasad nauki chrześcijańskiej, udowadnia sł także tym, że Stolica Apostolska wcześniej zatwierdziła uroczystość liturgiczną, niż pisma św. Małgorzaty Maryji. Nie pod wpływem prywatnego objawienia, ale na prośby wicrnych na wniosek Kongregacji Rytów ukazał się dn. 25 stycznia 1765 r. dekret Kongregacji Rytów, zatwierdzony dn. 6 lutego tegoż roku przez Papieża Klemensa VIII, udzielająy pozwolcnia Biskupom Polskim i Arcybractwu Rzymskiemu Serca Jezusowego na celebrowanie uroczystego świçta ku czci NSJ. Aktem

4s) Cfr. Litt. Enc. Miserentissimus Redemptor: A. A. S. 20. 1928, pp. 167-168. 
tym Stolica Apostolska wyraziła życzenie, żeby kult już istniejący i kwitnący rozwijał się jeszcze więcej w tym celu, by „ożywić symboiicznie wspomnienie miłości Bożej"99), która sprawiła, że Zbawiciel nasz złożył ofiare wynagradzającą za grzechy ludzkie.

Po tej pierwszej aprobacie udzielonej w formie przywileju i w pewnych granicach, nastapiła druga dopiero o wiek później, już o wiele donioślejsza w formie więcej uroczystej. Mówić chcemy tu o przedtem wspomnianym dekrecie św. Kongregacji Rytów z dnia 23 sierpnia 1856 roku. Poprzednik Nasz, Papicż Pius IX w odpowiedzi na liezne prośby i życzenia Biskupów Francji i całego prawie świata, rozszerzył uroczystość ku czci NSJ na cały świat i przepisał dla niej godne formy liturgiczne ${ }^{100}$ ). Zdarzenie to zasługuje na wieczną pamięć wierryych, albowiem, jak to czytamy w liturgii tejże uroczystości, ,odtąd kult NSJ jako rzeka wezbrana, usunąwszy wszelkie zapory, rozlał sie na cały świat".

Z tego cośmy dotą jasno wyłożyli, wynika, że wierni powinni czerpać znajomości kultu NSJ z Pisma świętego, Tradycji, Liturgii świętej, w nich colkrywac czyste źródła tego kuitu, jeśli chcą wniknąc w jego istotę, stamtąd w pobożnym rozmyślaniu czerpać pożywne owoce i wzrost swej gorliwości religijnej. Gdy wierni lepiej poznają ten kult i przy jego pomocy dążyć będą do wyższych celów, wtedy na pewno dojdą do słodkiej znajomości miłości Chrystusa, która stanowi istote życia chrześcijańskiego, jak o tym na podstawie osobistego doświadcze-nia mówi Apostol: ,Z tej przyczyny zginam kolana przed Ojcem Pana naszego Jezusa Chrystusa... aby dał wam według bogactw chwały swojiej, a za. sprawą Ducha Jego, wzmocnić się potężnie i wzrastać we wnętrznego czołwieka, tak aby przez wiare Chrystus zamieszkał w sercach waszych, a wy umocnieni i ugruntowani w miłości, byście mogli pojąc, jak miłość Chrystusa przewyższa wszelką wiedze i byli napełnieni całą pełnością Bożą"101). Serce Jezusa jest najwpanialszym obrazem obejmującym wszystką pełnię Boga, pełnię miłosierdzia, właściwą Nowemu Zakonowi, w którym ,okazała się dobroć i laskawość Boga." 102), albowiem, ,nie posłał Bóg Syna swego na świat, aby świat sadził, ale by świat był zbawiony przez niego" 103 ).

\section{d) charakter duchowy kultu NSJ}

Było to stałym przekonaniem Kościoła, nauczyciela praway, od chwili, gà tylko ukazały się pierwsze urzędowe wypowiedzi Kościoia w sprawie kultu NSJ, że zasadnicze współczynniki tego kultu, akty

4.) Cfr. A. Cardellini, Decreta authentica, 1857, n. 457, tom. 3, p. 174.

${ }^{100)}$ Cfr. Decr. S. C. Rit. apud N. Nilles, De rationibus festorum Sacramentissimi Cordis Jesu et purissimi Cordis Mariae, $5^{\mathrm{a}}$ ed. Innsbruck 1865, tom 1, p. 167.

101) Eph. 3, 14, 16-19.

$\left.{ }^{102}\right)$ Tit. 3, 4.

103) Jo. $3,17$. 
miłości i wynagrodzenia dla wyrażenia naszej czci dla nieskończonej miłości Boga dla czlowieka, wcale nie są zakażone materializmem ani zabobonami, ale że ten kult jest taką formą pobożności, w której doskonale objawia się religia prawdziwa, duchowa, zapowiedziana przez Boskiego Zbawicicla w rozmowie ze Samarytanką: ,Nadchodzi godzina j już nadeszła, że prawdziwi czciciele będą oddawać cześć Ojcu w duchu i w prawdzie. Bo i Ojciec takich szuka czcicieli. Duchem jest Büg, a ci, którzy go czczą, winni mu oddawaé cześć w duchu i w prawdzie" 104).

Nie godzi się mówié, że kontemplacja fizycznego Serca Jezusa przeszkadza w dojściu do intymnej miłości Boga i hamuje dusze w podchodzeniu do cnót najwyższych. Kościół odrzuca taką fałszywą naulse mistyczną i przez usta Poprzednika Naszego, Innocentego II poteppia fałszywe poglądy: „Dusze będące na drogach życia wewnętrznego, nie powinny spełniać aktów miłości do Dziewicy Najświętszej, do Świętyeh, do czlowieczeństwa Chrystusa, gdyż skoro to sa przedmioty zmysłowe. taka też jest miłość do nich, bo sam Bóg chce zająć miłość naszą i ją posiadaćc $\left.\dot{c}^{\prime 105}\right)$.

Kłoby tak myślał, ten widocznie uważałby, że symbolizm Serca Jezusowego nie rozciaga się poza oznaczenie miłości zmysolwej, i że wobec tego nie może stanowić nowego fundamentu w kulcic latrii, zastrze.żonym jeciynie dla tego, co jest istotnie Boskie. Otóż takie pojmowanie wartości symbolicznej świętych obrazów osądzi każdy jako calkowicie fałszywe, gdyż niesiłusznie zwęża ich znaczenie transcendentne. Teologowie katolicey, z Tomaszem św. razem uczą: „Nie okazujemy kultu religijnego obrazem, jako samym sobie, jako rzeczom, ale jako ubrazom, prowadzacym nas do Boga Wcielonego. Nasza postawa duchowa wobec obrazów nie zatrzymuje się na obrazach samych, ale idzie ku temu, czyj jest obraz, kogo obraz przedstawia. Dlatego kult religijny dla obrazów Chrystusa nie wypacza kultu latrii, ani nie psuje cnoty religijności ${ }^{109}$ ). Kult oảnosi się do samej osoby Słowa Wcielonego jako do celu bez względu na to, czy to będzie kult obrazów, relikwii, pamiątek narzędzi Męiki Chrystusa ,czy też jakaś rzecz przewyższająca wszystko swoją wymowną wartościa, to jest zranione Serce Jezusa Ukrzyżowanego.

Tak więc od rzeczy cielesnej, jaką jest Serce Chrystusa, od jego naturalnego symbolicznego znaczenia możemy wznieść do kontemplacji jego miłiści, widocznej dla zmyșłów naszych. Możemy i nawet powinniśmy postąpić wyżej, do adorowania i rozważania miłości własnej, aż wreszcie wstępując jeszcze wyżej, wznicść sic do rozmyślania i adorowania miłości Bożej Słowa Wcielonego. Wierzymy przecież, że w Osobie Chrystusa łączą się natura ludzka i Boża, i na tej podstawie mo-

104) Jo. 4, 23-24.

105) Innocentius XI. Constit, Ap. Coelestis Pastor, 19 Novembris 1687; Bullarium Romanum, Romae 1734, tom 8, p. 443.

${ }^{106}$ ) Sum. Theol. 2-2, q. 81 a. 3 ad 3 m: ed. Leon. tom 9, 1897, p. 180. 
¿zemy wyobrazić sobie te najściślejsze węzły, jakie istnieją pomiędzy zmysłową miłością fizycznego Serca Jezusa i podwójną miłością duchową, ludzką i Bożą. Te miłości obie nie tylko istnieją razem w świętéj Osobie Boskiego Zbawiciela, ale łącą się także pomiędzy sobą, miłość ludzka zmysłowa poddana jest miłości Bożej i maja analogiczne podobieństwo do miłości pierwszej. Nie twierdzimy tu, że w Sercu Jezusa istnieje i adorowany jest obraz formalny, jak się to mówi, czyli znak doskonały i absolutny jego miłości Bożej, bo przecież najgłębsza istota milości nigdy nie może być adekwantnie przedstawiona żadnym stworzonym obrazem. Chrześcijanin adorujący Serce Jezusa, adoruje wraz z Kościołem, znak i ślad miłości Bożej, która aż tak daleko się posunęła, że Sercem Słowa Wcielonego umiłowała rodzaj ludzki, obciążony wielu grzechami.

Jest więc konieczne, żeby w tym dziale teologii wymagajacym subtelności i roztropności, każdy uznawał prawdę naturalnego symbolu złączenia Serca Jezusa fizycznego z Osobą Słowa. Ta prawda opiera się na podstawie nauki o unii hipostatycznej. Kto by nie uznawal tej prawdy, odnowi stare fałszywe opinie, nie raz już przez Kościól odrzucone, sprzeciwiające się jedności w Chrystusie z tym, że każda natura zostaje odrębna i cała w sobie.

Ustaliwszy tę fundamentalną prawdę, zrozumiemy lepiej, że Serce Jezusa jest sercem Osoby Bożej, to jest Słowa Wcielonego, że niejako naocznie przedstawia całą miłość Boga do nas. Dlatego kult NSJ godzien jest być uważany jako wyznanie wiary chrześcijańskiej, jako wyznanie religii Chrystusa, Pośrednika pomiędzy Bogiem i czlowiekiem. Do Serca Boga można dojść tylko przez Serce Jezusa, jak to sam Jezus powiedział: „Ja jestem Droga Prawda, Życie - nikt nie przychodzi do Boga, jeno przeze mnie" ${ }^{107}$ ).

Zrozumiemy więc łatwo, że kult NSJ co do swej istoty jest kultem miołści, którą nas Bóg umiłował, jest również prakty`znym. wylionaniem tej miłości, którą żywimy dla Boga i ludzi. Albo użyjemy innych słów: ten kult ma jako przedmiot miłość Boga dla nas, Boga, którego adorujemy, któremu dziękujemy, którego naśladujemy. Celem tego kultu jest to, by miłość łączaca nas z Bogiem i ludźmi, wzrastała w nas i doskonaliła się, byśmy coraz usilniej każdego dnia wykonywali przykazanie ,nowe“, zlecone przez Boskiego Nauczyciela apostołom jako dziedzictwo, jako testament: „Przykazanie nowe daję wam, abyście się wzajemnie miłowali, jako ja was umiłowałem" ${ }^{108}$ ). Jest to przykazanie rzeczywiście „nowe“, właściwe tylko Jezusowi, jak o tym mówi Tomasz z Akwinu: „Różnica pomiędzy Starym i Nowym Testamentem jest krótko ujęta u Jeremiasza Proroka: dam domowi Izraela przymierze nowe“" ${ }^{109}$ ). To, że już w Starym Zakonie pr-ktykowano to

\footnotetext{
710) Jo. 14, 6.

104) Jo. 13, 34; 15, 12.

${ }^{109)}$ Jer. $31,31$.
} 
przykazanie ze strachu i z miłości świętej, przypisać trzeba Nowemu. Zakenowi, bo w St. Zakonie było to przykazanie nie jako jemu wlaściwe, ale jako przygotowanie Nowego Prawa" ${ }^{110}$ ).

\section{Praktyka kultu NSJ}

a) lepiej zrozumieć, zaktualizować

Dotąd pisaliśmy o właściwych zasadach tego kultu i jego wzniosłości. Zanim skończymy omawianie tych przepięknych i radosnych 'ematów, chcemy zachẹcić was, Czcigodni Bracia i za waszym pośrednictwem wszystkich naszych najdroższych w Chrystusie synów, by wszyscy staràli się odtąd gorliwiej rozszerzać i pogłębiać kult NSJ, gdyż jak ufamy wynikną z tego kultu przeliczne pożytki w naszych czasach. Wzywamy was w pełni świadomości naszego Apostolskiego posłannictwa, zwierzonego niegdyśs świętemu Piotrowi po jego trzykrotnym wyznaniu miłości.

Gdy należycie rozważymy wszystkie podstawy, na jakich opiera się kult NSJ, wtedy jasno zrozumiemy, że nie chodzi tu o jakąś zwyczajna formę pobożności, która można dowolnie stawiać niżej od innych form, lub nawet lekce sobie ważyć. Chodzi tu o praktykowanie takiej pobożności, która najlepiej może doprowadzić do zdobycia doskonałości chrześcijańskiej.

Bo jeśli , devotio = pobożność “ w pøjęciu teologicznym i powszechnie przyjetym, jak wyjaśnia Doktor anielski, znaczy wolę oddania sicbi€ na służbę Bogu, to jakąż służbę więcej wiążącą i więcej konieczna można sobie wyobrazić, więcej wzniosłą i słodką, jak służbę miłości?! Cóż możc być Bogu milsze nad posłuszeństwo milości, dawane Bogu z miłości?! Bo jakiekolwiek służenie jest pewnego rodzaju darem, a miłość ,to pierwszy dar, za którym idą dalsze dary" 112). Powinniśmy więc mieć w najwyższej czci tę formę religii, przy pomocy której człowiek więcej czci Boga i miłuje, łatwiej oddaje się Boskiej miłości. Formę tę przedstawił nam i zalecał sam Zbawiciel, a Papícżc wysławiali ją w wiekopomnych swoich pismach i dekretach. Dlatego postepowałby bardzo nieroztropnie, szkodliwie i Boga naszego obrażalb. ktoby sobic lekceważyl takie dobrodziejstwo przez Jezusa Chrystus powierzone Kościołowi. Skoro tak się sprawy mają, to wierni nie moga watpić, że gdy oddają cześć Najśw. Sercu Zbawiciela, równocześnie czynią zadość największemu swemu obowiązkowi służenia Bogu i poświęcenia Stwórcy swemu i Zbawicielowi siebie samych, wazelkiej swojej.osobistej działalności tak zewnętrznej jak i wewnętrznej. W ten więc sposób czynnie wykonują przykazanie Boze: „Będziesz miluwal

\footnotetext{
110) Comment. in Evang. S. Joann. e. 13; lect. 7, 3, ed. Parmae 1860. tom 10, p. 541.

111) Sum. Theol. 2-2, p. 82, a. 1: ed. Leon. tom 9. 1897, p. 187.

112) Ibid. 1, q. 38, a. 2: ed. Leon. tom 4, 1888, p. 393.
} 
Pana Boga twego z caiego serca twego, z całej duszy twojej, z całego umysłu twojego, ze wszystkich sił twoich" ${ }^{113}$ ). Przez to zdobywają takie pewność, że do miłowania Boga nie skłania ich głównie żadna korzyść prywatna, mająca na oku ciało lub dusze, obecne lub wieczne życie, alc samą dobroć Boga, któremu chcą być oddani i posłuszni, któremu chcą składać zawsze akty miłości, adoracji, dziękczynienia.

Gdyby zaś tak nie było, to kult NSJ zupełnie nie ocipowiadalb. właściwym, istotnym cechom religii chrześcijańskiej, gdyż człowiek wtedy czciłby nie Bożą miłość, ale coś innego. Dlatego słusznie zarzuca się nieraz zbytnią miłość siebie i troskę o doczesność tym, którzy zupelnie źle pojmują tę najwznioślejszą formę pobożności i niewłaściwie ją praktykują. Dlatego niech wszyscy będą o tym najmocniej przekonani, że w tym kulcie NSJ zewnętrzne praktyki pobożności nie zaimują pierwszego miejsca, i że ten kult jest ważny dlatego, że dajo wiele dobrodziejstw. Chrystus Pan dlatego do objawień prywatnych dołączył pewne obietnice o łaskach, by ludzie najgłówniejsze obowiązki religii katolickiej miłości i ekspiacji wykonywali więcej gorliwie i taik lepiej zabezpieczyli swoje i bliźnich zbawienie..

Do tej właśnie formy pobożności usilnie wzywamy wszystkich $\mathrm{Na--}$ szych w Chrystusie umiłowanych synów, i tych, którzy już przyzwyczaili się do czerpania łask ze zdrojów wód zbawczych wypływajacych ze Serca Zbawiciela, i tych, którzy z boku, jako widzowie z cickawościa, ale $\mathrm{i}$ z wątpliwościami patrzą na sprawy tego kultu. Niech teraz pilnie rozważą, że tu chodzi o kult już od dawna w Kościele istniejący, mocna oparty na Ewangeliach. Kultowi temu sprzyja caikowicie Tradycja i Liturgia święta, a Papieże rzymscy wiele razy i obszernie głosili jego pochwały. Nie wystarczało im to, że ustanowili święto ku czci Serca Zbawiciela i rozszerzyli je na cały świat, ale dokonywail często uroczystych konsekracji całego rodu ludzkiego Najw. Sercu Jezusa. $\left.{ }^{114}\right)$. Dodajmy tu także i wspomnijmy te przebogate i rozliczne owoce kultu, jak niezliczone nawrócenia na religię chrześcijańską, ożywienie religii u wielu ludzi, silniejsze i ściślejsze złączenie wielu chrzościjan z umiłowariym Zbawicielem - a to wszystko szczególniej często i obficie okazało się w ostatnich dziesiątktch lat.

Gdy oglądamy okolo nas to godne podziwu zjawisko, ten wspaniały rozwój kultu NSJ we wszystkich klasach luỏzi, przeżywamy wieka radość w sercu i najpierw Zbawicielowi dzięki należne składamy za jego dobroć nieskończoną, nastẹpnie gratulujemy z ojcowską radościa tym wszystkim, duchownym i świeckim katolikom, którzy wiele pracy włożyli w rozwój tego kultu.

113) Marc. 12, 30; Matth. 22, 37.

144) Cfr. Leo 13, Enc. Annum Sacbrum: Acta Leonis, vol. 19, 1900, p. 71 sq.: Decr. S. C. Rituum, 28 Iun. 1899, in Decr. Auth. 3, n. 3712; Pius XI, Enc. Miserentissimus Redemptor: A. A. S. 1928. p. 177 sq.; Decr. S. C. Rit. 29 Ian. 1929: A. S. S. 21, 1929, p. 77. 


\section{b) kult NSJ wobec potrzeb aktualnych Kościola}

Chociaż, Czcigodni Bracia, nabożeństwo do NSJ wielkie wszędzie przynioslo owoce dla życia chrześcijańskiego, to jednak wiemy, że Kościol walczący i wędrujący na tej ziemi, a zwłaszcza ludzka społeczność świecka dotąd jeszcze nie osiągnęła pełnej formy doskonałości, jakaby odpowiadała życzeniom Jezusa Chrystusa, Oblubieńca Mistycznego Kościola. Liczni bowiem synowie Kościoła grzechami swoimi plamia to Oblicze, które na sobie winni odzwierciedlać. Jeszcze nie wszyscy wierni jaśnieją tą świętością obyczajów, do której ich Bóg powołuje. Nie wszyscy grzesznicy wrócili do domu Ojca, który przez grzechy opuścili, do domu Ojca, w którym dostaliby najpiękniejszą szatę ${ }^{115}$ ) i pierścień, symbol wierności dla Oblubienca ich duszy, nie wszyscy jeszcze poganie włączeni zostali do Ciała mistycznego Chrystusa. To nie dosyć. Gorzki ból sprawia nam słabnąca wiara dobrych, których dusze zwiedzione oszukańczymi pożądaniami dóbr ziemskich słabną w gorliwości i miłości Bożej, gaśnie w nich powoli miłość - jeszcze więcej Nas krzyżują działania ludizi bezbożnych, którzy jakby podnieceni przez wrogie siły piekielne, teraz coraz więcej zieją nienawiścią nieprzejednaną do Boga, Kościoła, a przede wszystkim do Boskiego Zbawiciela, źródła miłości Bożej dla ludzi, o którym Doktor mediolański mówi: „Piotra pytają o to, o czym wątpi, ale nie wątpi Pan, który pyta, nie by się dowiedzieć, ale by pouczyć tego, którego po swoim Wniebowstạpieniu zostawił wśród nas jako zastępcę swej miłości“ "116).

Nienawiść do Boga i do tych, którzy są prawowitymi zastẹpcami Boga, jest taką zbrodnią, że większej już chyba czlowiek popełnić nie może, człowiek stworzony na obraz i podobieństwo Boże, przeznaczony do przyjażni doskonałej z Bogiem mającej trwać także w niebie. Człowiek przez nienawiść do Boga najbardziej odrywa się od Dobra najwyższego, nienawiść ta skłania go do odrzucenia od siebie i swoich najbliższych wszystkiego, co od Boga pochodzi, co łączy z Bogiem, to jest do odrzucenia prawdy, cnoty, pokoju, sprawiedliwości ${ }^{117}$ ).

Biadać trzeba, niestety, gdy się widzi, jak rośnie liczba tych, którzy chełpią się wrogością wobec Boga, jak się szerzą teorie materializmu, jak coraz wyżej wznosi żądanie swobody dla namiętności i wyuzāania. Cóż dziwnego, że wobec tego ziębnie miłość w sercach wielu, miłość, najwyższe prawo religii chrześcijańskiej, podstawa najsilniejsza prawdziwej i doskonałej sprawiedliwości, źróđło pokoju i czystej radości?! Zbawiciel upominał niegdyś: „Ponieważ rozmnoży się nieprawość oziębnie miłość wielu" ${ }^{118}$ ).

115) Luc. 15, 22.

116) Exposit. in Evang. sec. Lucam, 1, n. 175; P. L. 15, 1942.

${ }^{117}$ ) Cfr. S. Thom. Sum. Theol. 2-2, q. 34, a. 2: ed. Leon. tom. 8, 1895, p. 274.

118) Matth. 24, 12. 
c) Serce Jezusa - sżtandar zbawienia dia wspótczesnego świata

$\mathrm{Na}$ wiảok takich mas zła, które dzisiaj, więcej niż kieđiyindziej trapia, jednostki, rodziny, narody i świat caly, gdzie, Czcigodni Bracia, znajdziemy lekarstwo? Czy znajdzie się lepsza forma pobożności, niż kult NSJ, więcej odpowiadająca cechom religii katolickiej, nadająca się więcej dla dzisiejszych potrzeb duchowych Kościoła i rodu ludzkiego? Jaka akcja religijna byłaby znakomitsza, milsza, zdrowsza, skoro ten właśnie kult cały zmierza do miłości Bożej? $\left.{ }^{119}\right)$. Cóż bardziej skuteczne nad milość Chrystusa, kłórą kult Serca Jezusa coraz więcej co dnia wzmaga się i rozwija? Cóż skuteczniej poruszy wiernych do wprowadzenia w życie prawa Ewangelicznego? Gdy się zaniedba to prawo miłości, jak upomina Duch święty: „Dziełem sprawiedliwości pokój“ ${ }^{120}$ ), czyż zdolamy kiedyś zdobyć prawdziwy pokój?

Za przykładem Naszego bezpośredniego Poprzednika, kierujemy do wszystkich Naszych synów w Chrystusie to upomnienie, które Leon XIII u schylku minionego wieku kierowal do wszystkich chrześcijan, do tych wszystkich, którzy poważnie troszczą się o zbawienie swoje i calego społeczeństwa: „Oto przed oczyma wszystkich pojawia się znak inny, opatrznościowy znak Boży, Najświętsze Serce Jezusa, jaśniejące niezwykłym blaskiem wśród płomieni - w nim nadzieja wszystkich, od̉ niego możemy wyprosić i otrzymać zbawienie" ${ }^{121}$ ).

Jest naszym najgorętszym życzeniem, by kult NSJ stał się sztandarem jedności, zbawienia, pokoju dla wszystkich chrześcijan, którzy pracują gorliwie i usilnie nad wprowadzeniem Królestwa Bożego w świecie. Niech jednak nikt nie myśli, że przez ten kult pomniejszone zostaną inne formy religijności, którymi lud chrześcijański pod przewodnictwem Kościoła czci Boskiego Zbawiciela. Przeciwnie, gorliwy kult NSJ przyczyni się do rozwoju kultu dla świętego Krzyża i rozwoju miłości do Najśw. Sakramentu. Wolno nam to stwierdzić, co zresztą głoszą także objawienia udzielone św. Gertrudzie, św. Małgorzacie Maryji: nikt nie zdoła pojąć krzyża Chrystusa, jeśli nie wniknie w mistyczne głębiny Serca Jezusa. Niełatwo też zdoła ktoś pojąć siłę miłości, która skłoniła Jezusa, by się stał naszym pokarmem, jeśli nie będzie miał szczególniejszej czci dla Eucharystycznego Serca Jezusa. Zadaniem tego Serca jest, by użyć słów Leona XIII, przypominać nam akt najwyższej miłości, w którym Zbawiciel wylał wszystkie bogactwa swego Serca, by zostać z nami aż do końca wieków przez ten przedziwny Sakrament Eucharystii“ 122). Albowiem, „nie najmniejszą cząstką

119) Cfr. Miserentissimus Redemptor: A. A. S. 20, 1928, p. 166.

$\left.{ }^{120}\right)$ Is. $32,17$.

121) Enc. Annum Sacrum: Acta Leonis vol. 19, 1900, p. 79; Enc. Miserentissimus Redemptor: A. A. S. 20, 1928, p. 167.

${ }^{122}$ ) Litt. Apost. quibus Archisodalitas a Corde Eucharistica Jesu ad S. Joachim de Urbe erigitur, 17 Febr. 1903: Acta Leonis, vol. 22, 1903, p. 307 sq.; cfr. Enc. Mirae caritatis, 22 Mai 1902: Acta Leonis vol. 22, 1903, p. 116. 
Serca Jezusa jest Eucharystia, którą nam dał z tak wielkiej Serca sweǵo miłości" 123).

Wreszcie pragniemy mocne postawić zapory przeciw bezbożnym atakom wrogów Boga i Kościoła, pragniemy sprowadzić społeczeństwa do miłości Boga i bliźniego i dlatego nie wahamy się twierdzić, ze kult NSJ jest najskuteczniejszą szkołą miłości Bożej. Podkreślamy: szkołą miłości Bożej, na której oprzeć się winno Królestwo Boże w pojedynczych duszach, w rodzinach i w narodach, jak to tenże Nasz Poprzednik mądrze wskazał: „Królestwo Chrystusa bierze moc swoja i formę od Bożej miłości. To jest jego podstawą i celem: miłować w świętości, w ładzie i porząảku, stąd wynikną następujące konieczne normy: doskonale spelniać swoje obowiązki — nikomu nie czynić żadnej krzywdy - uważać, że dobra ziemskie są niższe od dóbr Bożych miłość Bożą stawiać ponad wszystko inne“ ${ }^{124}$ ).

By zaś z tego kultu NSJ spłynęły obfite duchowe korzyści na rodziny chrześcijańskie, na wszystkich ludzi, niech wierni starają się dołączyć ściśle do tego kultu kult dla Niepokalanego Serca Maryji. W dziele Odkupienia z woli Bożej Najśw. Panna Maryja była jak najściślej złączona z Chrystusem. Z miłości Chrystusa i Jego Męki oraz z. miłości i cierpień Matki, wnętrznie ze sobą złączonych, powstało nasze zbawienie. Wypada $z$ tego najoczywiściej, że skoro chrześcijanie przez Maryję od Chrystusa otrzymali Boże życie, by po spełnieniu kultu należnego Sercu Jezusa uczcili także Najsłodsze Serce Matki Nie-bieskiej pobożnością, miłością, dziękczynieniem, wynagrodzeniem. Zgodnie z tym przemądrym i łaskawym zrządzeniem Bożej Opatrzności i My sami poświęciliśmy uroczyście Kościół święty i cały świat Niepokalanemu Sercu Błogosławionej Dziewicy Maryji ${ }^{125}$ ).

\section{d) godnie uczcić setnq rocznice uroczystości NSJ}

W ciągu roku bieżącego, jak to wyżej już zaznaczyliśmy, dobiega szczęśliwie do końca pierwsze stulecie od chwili, gdy na zarządzenie Poprzednika Naszego, Piusa IX, zaczęto w całym Kościele obchodzić liturgiczną uroczystość ku czci NSJ. Gorąco pragniemy, Czcigodni Bracia, by wspomnienie tego stulecia było połączone $\mathrm{z}$ uroczystymi obchodami, jako wyraz chrześcijańskiej radości i pobożności, że szczególniejszą gorliwoscią urządzonymi publicznymi adoracjami, dziękczynieniem, w złączeniu w miłości chrześcijańskiej z tym narodem, z którego nie bez tajemniczego zrządzenia Boga, wyszła świc̨ta dziewica, która stała się heroldem i głosicielką tego kultu.

Krzepimy się słodką nadzieją i już prawie wdizimy, jak niezwykłe wynikną owoce duchowe kultu NSJ, jeśli teraz wszędzie należycie

123) S. Albertus M. De Eucharistia, dist. 6, tr. 1, c. 1; Opera Omnia ed. Borgnet, vol. 38, Parisiis, 1890 , p. 358.

$\left.{ }^{124}\right)$ Enc. Tametsi: Acta Leonis, vol. 20, 1900, p. 303.

125) Cfr. A. A. S. 34,1942 , p. 345 sq 
zostanie on zrozumiany i pracowicie wykonany. Slemy ku Bogu pokorne modły, by te nasze najgorętsze pragnienia wesprzeć raczył pomocą swoich łask. Pragniemy też by za łaską Bożą coraz więcej rosła z tych uroczystości pobożności wiernych do NSJ, by wszędzie rozszerzało się, ,królestwo prawdy i życia, królestwo świętości i laski, królestwo sprawiedliwości, miłości, pokoju“" ${ }^{126}$ ).

Jako zapowiedź tych darów niebieskich, udzielamy z całego serca Apostolskiego Blogosławieństwa wam samym, Czcigodni Bracia, duchowieństwu, wiernym waszej duszpasterskiej trosce poświęconym, szczególniej zaś tym, którzy wszystkimi środkami usiłują rozszerzać, rozwijać, pogłębiać kult NSJ.

Dan w Rzymie, u św. Piotra, dnia 15 maja 1956 roku, ośmnastego roku Naszego Pontyfikatu - Pius XII.

Katowice

Przettumaczyt: Ks. MICHAE RĘKAS

126) Ex. Misc. Rom. Praef. Jesu Christi Regis. 